\title{
Determinants of Commercial Banks Profitability: Empirical Evidence from Ethiopian Commercial Banks
}

\author{
Alene Asnake Mamo \\ Department of Accounting and Finances, University of Gondar, Gondar, Ethiopia
}

\begin{abstract}
Commercial Banks play an important role in contributing to a country's economic development. Accordingly understanding factors affecting commercial banks profitability is essential. The main objective of this study is pointing out the variables that have impact on the determination of Ethiopian commercial banks profitability. The data was collected from National bank of Ethiopia annual reports and from 17 Ethiopian commercial banks, which covers from 2005 to 2019. The explanatory variables covered under this study were Bank Specific (Capital Adequacy, Bank Size, Deposit Ratio, Credit Risk and Fund Cost), Macro-Economic (Inflation Rate, Real Economic Growth Rate \& Foreign Exchange Rate) and industry specific (Lending Interest rate). ROA, ROE \& NIM was used as dependent variables to measure profitability. Fixed effect model with bootstrap estimation was used to analyze the effect of those explanatory variables on ROA. On the other hand, PSCEs regression and PSCEs regression with transformation of the data to logarithmic value were done to ROE \& NIM respectively. The STATA 14 output depicts bank size capital adequacy and deposit ratio has a positive and significant relationship with Ethiopian commercial banks profitability. The other important bank specific explanatory variable is liquidity, which has a negative and significant relationship with banks profitability (measured by NIM). the last significant variable is lending interest rate, which has a negative significant influence on ROA \& ROE. Unexpectedly the three macro-economic variable haven't a significant influence on ROA, ROE \&NIM. So it is suggested that Ethiopian commercial banks should focus on bank specific and industry specific variables to increase their profitability.
\end{abstract}

Keywords: Commercial Banks Profitability, Ethiopia, Bank Specific, industry specific and Macroeconomic

DOI: $10.7176 /$ RJFA/11-15-04

Publication date:August $31^{\text {st }} 2020$

\section{Introduction}

1.1 Background of the study

A financial institution is an establishment that conducts financial transactions such as investments, loans and deposits. Almost everyone deals with financial institutions on a regular basis. Everything from depositing money to taking out loans and exchanging currencies are done through financial institutions (Howells \& Bain, 2007). A bank is commonly recognized as one of the financial institution which provides essential banking services such as accepting deposits and provides various types of loans (Fentaw, 2012). It is obvious that Commercial Banks play a vital role in the economic development of a country. If the banking sector does not make a profit as a result those banks will leave the business, finally the consequence to the overall economy could be massive. The poor performance of the banking business affected the U.S. economy and also the growth of global economy until this period. One of the main causes is the poor lending policies and decisions made by U.S. banks (Madura, 2010) this is practical example, again in Asia although the losses in banking sectors are not as serious as U.S., it is also have a significant impact on their economy (Said \& Tumin, 2011). Thus financial institutions mainly a bank must be profitable in order to ensure the stability of the financial system as well as the overall economy.

Many scholars have make an effort to find out the factors affecting banks profitability. Management is concerned in identifying the determinants to their performance, in order to adjust their policy over them and increase their success. Likewise, investors by understanding such type of information are able to make good decisions regarding to their actual and potential investment (Tsalkitzidis, 2011). According to Gemechu (2016) the investigation of the most important factors that have impact on bank profitability has also address the attention of decision makers and of the researchers as the banking industry is vital for developing a national economy and establishing the financial stability. Moreover, the severe implications of the recent international financial crisis on the banking sector bring back to the center of attention to the understanding of banks profitability determinants (Roman \& Danuletiu, 2013). Throughout the last 20 years, the banking sector in Africa has experienced major transformation in its working environment. In a number of countries, financial sector reforms have been executed. In these reforms, the role of commercial banks has remained crucial in financing economic activities in the various parts of the markets especially in Sub-Saharan Africa (Francis, 2013). According to Chinoda (2014) profitability for African banks can achieved if bank managers and policy makers address both internal as well as macroeconomic factors, that have effect on profitability. On the other hand, the banks in Ethiopia have sustainable profit trends compared to other east African banks. This has helped them to get more funds from the public and enhance their capital buffers, and remain solvent but there are disparities on private banks financial performances. 
Therefore, since banks' profitability will generally vary directly with the riskiness of their portfolios and operations, they need always to carefully identify, assess, monitor and control risks associated with internal factors, industry level factors and external factors (Fortun News, 2015).

To sum up the study of commercial banking determinant factors are undeniably desired since, commercial banks not profitable means the entire economy may become unstable and will be adversely affected because banks play a prominent role in the economic development of a country. So this paper covered variables bank specific factors (capital adequacy, bank size, liquidity, credit risk, deposit ratio \& funding costs), macroeconomic factors (economic growth, inflation, foreign exchange and interest rate) and industry specific (lending interest rate) to study their effect on the profitability of commercial banks exist in Ethiopia.

\subsection{Statement of the Problem}

The soundness and well existence of the financial institutions could be done by assessing their financial performance and positions, and make an action accordingly to turn the condition to the benefit of the individual institutions, financial system and to the overall economy. Generally, in order to survive in the long future it is important for banks and other financial institutions to identify what are the determinants of profitability (Dani, 2014). It is obvious that profitability is crucial for a bank to continue ongoing activity and for its shareholders to obtain fair returns and wealth maximization. Likewise, it is also vital for bank administrators since it guarantees more flexible in their activity, even in the situation of a riskier business environment (Ponce, 2009). According to Fentaw (2012) performing studies on banks performance is essential not only for that of the information it provides about the wellbeing of the economy in any period, but also because it is a fundamental determinant of growth, employment and the overall development of a given countries.

Different scholars have done their study on the topic factors that affect the Profitability of Commercial Banks on different time and several countries of the world. But the result of those studies does not show a common determinant factors, to give empirical ground the researcher try to show some scholars result on a specifically selected variables; According to Hoffmann (2011) an independent variable Bank Size have negative and significant effect on profitability, on the other hand according to Davydenko (2010) Bank Size have a positive relationship with bank profitability, and some other studies like Dawood (2014) indicated that Bank Size and profitability have no relationship. Again for Liquidity effect on profitability there are inconsistency in some scholars; the research done in Jordan by Alzorqan (2014) found that there is positive relationship between liquidity and bank profitability. But most literature like (Ayadi \& Boujelbene, 2012 and Samuel, 2015) found negative relationship regarding to commercial banks profitability and liquidity risk. Mostly, the results for other variables have also not unique as far as the researcher try to find the reason for the divergence of outcomes in those scholars can be; one due to continuous change in globalization, deregulation, industry level competition and rivalry from the non-banking financial institutions and volatile market dynamics (Yalemselam, 2019). Two the reason for the dissimilarity of the researchers' result may arise from the measurement of the dependent variables by using different ratios like Return on Asset, Return on Equity and net interest margin. Some studies like Hassan \& Bashir (2002) indicates that basic measure of bank profitability is return on assets $(R O A)$. The other studies like Roman \& Danuletiu (2013) argued that return on equity is the best masure of banks profitability. Again some other scholars and researchers noted using Net Interest Margins measure banks profitability than the other, since banks profit is mostly tied up with interest revenue and interest expense. To handle such problem, in this study those three bank profit measurement ratios was used as a dependent variable. In case of Ethiopia there are academicians that done their thesis and journal articles on the determinants of commercial banks profitability such as; Elefachew \& Rao (2016); Habtamu (2012); Fentaw (2012); Gemechu (2016); Rao \& Tekeste (2012) and others, but to the researcher's knowledge there are few studies that incorporate variables like interest rate, deposit ratio and foreign exchange rate. That's why this paper was tried to incorporate the above listed three variables and used as a dependent variable that are used by different scholars separately namely Return on Asset, Return on equity and Net Interest Margin.

\subsection{Objective of the Study}

\subsubsection{General Objective}

The general objective of this study was studying factors that determine the profitability of Ethiopian private commercial banks under the study period.

\subsubsection{Specific Objectives}

To examine the effect of bank specific factors (capital adequacy, bank size, liquidity, credit risk, funding cost and deposit ratio,) on Ethiopian commercial banks profitability. To find out the effect of industry specific variables (lending interest rate). To identify the effect of macroeconomic factors (real economic growth inflation, and foreign exchange rate) on Ethiopian commercial banks profitability. To forward possible recommendations to Ethiopian commercial banks and regulatory bodies based on the findings of the study. 


\subsection{Scope of the Study}

The study covered 17 commercial banks of Ethiopia by using their $15 y$ ear financial data from $2005-2019$. The variables covered under this study includes bank specific (capital adequacy, bank size, deposit ratio, liquidity, credit risk, and funding cost), industry specific (lending interest rate) and macroeconomic factors (economic growth, inflation, and foreign exchange rate).

\section{Literature Review}

\subsection{Bank Profitability and Measurement}

Profit, more commonly referred to as income after deducting taxes, is an amount that depicts how well the bank is doing because it is the figurative value that the bank has available to keep as retained earnings or be distributed to stockholders as dividends. Although net income gives an idea of how well a bank is doing, it suffers from one major drawback: It does not adjust for the bank's size, thus it is difficult to compare how well one bank is doing relative to another (Yalemselam, Nov. 1 2019). In any way the primary means of evaluating internal performance is by analyzing financial statements, the financial positions and its performance. Various financial ratios are usually used to evaluate the performance of financial intermediaries specifically banks (Adeusi, Aluko, \& Klapo, 2014). Financial ratios typically give a broader understanding of the bank's financial condition as they are constructed from financial statements contained its statement of financial positions and income statement. But which ratio gives the best measurement for banks profitability is controversial. The commonly used ratios are Return on Asset (ROA), Return on Equity (ROE) and Net Interest Margin (NIM). ROA ratio is calculated as net profit after tax divided by the total assets. This ratio measure for the operating efficiency for the company based on the firm's generated profits from its total assets. ROE is the ratio of net income after taxes to common equity measures the return earned on the ordinary stockholder's investment. NIM is the difference between interest income and interest expenses as a percentage of total assets (Majid Kabajeh, AL Nu'aimat, \& Dahmash, 2012). As stated in the statement of the problem section in this study all the above ratios used as a dependent variable.

\subsection{Review of Related literatures}

It is undeniable there are many studies prepared by A number of researchers', academician, and other concerned bodies on the determinants of banking profitability. The frequently used determinants of banks' profitability that have been used by scholars are bank size, overhead cost management efficiency, funding cost banks' capital, liquidity, credit risk, asset diversification, foreign ownership in banks, economic growth rate, market concentration and inflation rate. Here under some of the studies what are related with banks profitability is reviewed;

According to Garza-Garcia (2009) a research conducted in Mexico shows that bank profits have been affected by greater market share. Profits continue over time but adjust slowly to their normal level, suggesting that the banking sector is not very competitive. Moreover, there is no indication of a positive relationship between greater efficiency and bank profits, which is measured by Return on asset and return on equity. Again even though capitalization levels increase bank profits, liquidity risk decreases both ROA \& ROE. The other researchers Ani et al. (2012) done a study on 15 Nigerian banks bay gathering 10year panel data, the outcomes of regression confirmations that increase in bank size may not necessarily lead to higher profits as a result of diseconomies of scale; higher capital-assets ratio and loans and advances have significant effect on banks profitability. According to Kosmidou, Tanna \& Pasiouras (2012) in which the study conducted on United Kingdom owned commercial banks it states that capital adequacy of the banks is the most substantial factor that affect profitability measured with ROA, the other significant factors are being efficiency in expenses management and bank size. According to those researchers the internal determinants are robust to the inclusion of extra macroeconomic and monetary market measures of bank overall performance, which add little to the explanatory power however seem to have positively influence profitability. As per the study of Roman \& Danuletiu (2013), liquidity have a negative effect on banks profitability in Romania and Bulgaria. Economic growth is an important external factor that influences banks profitability, although it's worth mentioning that the sign of the coefficient is different from one country to another. It is found to have a negative effect on profitability of some selected countries like Bulgaria, the Czech Republic and Hungary. According to those researcher banks profitability and deposit ratio have a positive relationship only in Lithuania. Nevertheless, the coefficient is negative and statistically significant for the banks in Hungary, Poland and Romania. Funding costs $(\mathrm{FC})$ had an important impact on the banks from Bulgaria, Hungary and Lithuania but the coefficient is negative just in the case of Hungary and Lithuania. In this period, Bulgarian banks have enhanced their funding structures by replacing volatile wholesale and parental funding with steady customer deposits.

Athanasoglou et al. (2005) carry out their investigation by Generalized Method of Moments (GMM) techniques to a panel of Greek banks that covers the period 1985-2001 the result shows the relationship of some internal factors that is computed from statement of financial performances and positions with banks performance in Malaysia and China indicate that the variable of credit risk is negatively related to ROA for banks in both countries. On the other hand, for the ROE, the credit risk is negatively related to Malaysian banks profitability 
only. The relationship between capital adequacy and bank performance is somewhat mixed. Capital adequacy and the ROE of China's banks profitability are positively and significantly related. Operating expenses has a negative significant effect on banks performance in both countries when performance is computed with ROA. When ROE is employed as a measurement of banks profit, this relationship remains true only for China. A study by Tsalkitzidis (2011), the profitability determinants of commercial banks in Greece and Balkans found that both bank size and capital adequacy have a positive significant effect. But, the variable of bank-size is statistically significant only for the crisis period Greece and Balkan, whereas capital adequacy is significant in both pre-crisis period and in the crisis period. Regarding to the external variables, GDP is significant during financial crisis but other macroeconomic variables seems insignificant. GDP appears to have a positive relationship with Return on Asset for the pre-crisis period, though it has a negative one for the crisis or post crisis condition. According to Roman \& Danuletiu (2013) who investigate the factors that have significant effect on profitability of Romanian commercial banks, for the period covering 2003 - 2011. The finding of this study shows that commercial banks profitability in Romanian is influenced by both internal factors (bank specific) and changes in the overall economy (macro level factors. In regard to bank specific factors, the results reflect that bank profitability is significantly influenced by asset quality, management quality and banking liquidity. Among external factors, the result shows banking concentration and economic growth rate have a significant impact on bank profitability.

The determinants of Islamic bank profitability are somewhat odd in its sign and intensity compared with the other commercial banks. Here the researcher goes to review one study that focused on Islamic banks contained data of 21 countries over the period 1994 - 2001 by Hassan \& Bashir (2002). This study reports that capital adequacy and Islamic banks profitability are positively related, however risk and bank size negatively affect profitability of Islamic banks. On the other hand, results this study discovered that customer and short term funds to total assets ratio lead to low non-interest margins. Finally, they conclude that GDP per capita and inflation have no significant influence on Islamic banks profitability, although growth of GDP affects profits significantly.

A study based on Balanced panel data of eight Ethiopian commercial banks that cover up the period between 2002 and 2012 was conducted by Gemechu (2016). The study used ordinary least square (OLS) method to see the effect of determinants on profitability of Ethiopian commercial banks. The result confirms that bank size capital adequacy and liquidity risk have statistically significant and positively related with banks' profitability. Conversely, variables like credit risk, expense management and regulation have a negative and statistically significant relationship with banks' profitability. in this study economic growth, interest rate spread and exchange rate are statistically significant and positively related with banks' profitability. According to Rao \& Tekeste (2012) investigation on determinant of Ethiopia commercial banks profitability using unbalanced panel data set of banks for the year from 1999 to 2009 . The finding of this study depict that the most determinants of bank profitability in Ethiopia are the bank specific factors, factors that are bank's management has control like bank's capital structure, liquidity, credit risk, loan portfolio, asset quality, and expense management. On the other hand, the external factors are found to be statistically insignificant, but their signs have important policy implications, and thus require the attention of policy makers and bank regulators. As stated by Samuel (2015) on examination of the determinants of commercial banks profitability in Ethiopia by using panel data of eight commercial banks for the period 2002 to 2013, bank size, capital adequacy and GDP are statistically significant and positively related with bank's profitability. Conversely, variables like liquidity risk, operational efficiency, funding cost and banking sector development are statistically significant and negatively related with banks' profitability. Yet, the result for management efficiency, employee efficiency, inflation and foreign exchange rate are statistically insignificant.

\subsection{Determinants of Bank Profitability \\ 2.3.1 Bank Specific Factors that Determine Profitability of Banks Capital Adequacy}

Capital adequacy expressed by the ratio of total capital to total asset. It plays a major role in determining bank profitability, to attain an efficient intermediation practice, and finally to provide desired levels of specific banks products or service higher capitalization will increase the profitability since banks with higher capital ratio can engage in prudent lending, banks are able to minimize their funding cost because large share of capital is a key indicator of creditworthiness (Chinoda, 2014). According to Davydenko (2010) banks with high capital adequacy have lower perceived risk and in line with the finance theory should produce lower returns. However, banks with a higher level of capital are viewed as having a protection in case of liquidation. Being better insured from bankruptcy they also have a lower cost of capital contributing to their profitability highly capitalized bank has more flexibility to both pursue surprising opportunities and deal with unforeseen losses and hence more profitable. Therefore, capital adequacy ratio is an internal variable that may have effect on profitability. The result may run in both directions, either it can be positive or negative.

\section{Bank Size}

Natural logarithm of bank total assets is mostly used as a measure of bank size. This variable will depict existence of economies of scale or diseconomies of scale in banks. The basic theory is that large banks are more profitable 
than small banks due to their ability to diversify and reduce risk. Increase in bank size is expected to be accompanied by rise in profitability but if size becomes extremely big, it could bring negative effects on bank performance (Athanasoglou et al., 2005). The belief along with economists is that bank size and profitability is positively related because of economies of scale up to a certain extent. This is why larger banks are able to have more diversification and provide more products to customers than smaller banks. Yet, this rational fails to take into account certain side effects like when banks become much complex to manage efficiently (Schipper IV, 2013). Thus, on one side the bank size can have positive effects on probability where there are considerable economies of scale. On the other side still, in the case of the banks that become extremely large, the size can have a negative effect upon profitability because of the agency costs, the overhead of bureaucratic processes and other costs related to the administration of very big firms. According to Rao \& Tekeste (2012) bank size should be included as bank specific factor to give an explanation for size related economies of scale or diseconomies of scale in banking sector. They also argued that larger banks could reap more profits due to scale economies or scope economies. Despite the fact that, there is no consensus as far as the relationship between bank size and bank profitability is concerned. Liquidity

Liquidity can be defined as the ratio of total liquid assets (the sum of cash holdings, balances at central and other banks, market securities etc.) (Sharma \& Gounder, 2012). Liquidity is company specific determinant that is straightforwardly linked with bank cash management. Small level of liquidity is ground reality of failure of banking and it draws a big deal of scholars and researchers thinking to see the effect of liquidity on profitability. (Usman, Tarig, \& Mir, 2014). The research done in Jordan by Alzorqan (2014) found that there is positive relationship between liquidity and bank profitability. But most literature like (Ayadi \& Boujelbene, 2012 and Samuel, 2015) found negative relationship regarding to commercial banks profitability and liquidity. In theory there is a trade of regarding to the relationship between Liquidity and banks profitability, because holding highly liquid asset does not go with providing long term loans that create an interest revenue to the commercial banks. On the other hand, banks remain liquid at any time (Athanasoglou et al., 2005). So in this study the researcher investigates the effect and

\section{Credit Risk}

Credit risk can be defined as general reserves for doubtful loans and advances to gross loans. The ratio measures the competency of bank managers to examine the potential variation in net income following on non-payment or delayed payment on credit. Therefore, income may decline when loans are not collected at all or in time. Still, in times of stable good profits, loan loss provisions probably reduced as stability of cash inflows permit banks to better handle unexpected defaults. Higher provisions for loan may indicate both a higher likelihood of potential losses and also a timely recognition of weak loans by wise managers (Sharma \& Gounder, 2012).The severe banking problems have resulted from in ability of banks to recognize the impaired assets and make reserves for their cancellation. An immense consideration have given to these assets in that would be provided by improving the transparency of the financial systems, which will help banks to assess their credit risk more effectively and keep away from exposures of dangerous problems (Ayadi \& Boujelbene, 2012).

\section{Deposits}

This variable is not considered in most of the study related to commercial banks profitability. Deposits ratio is considered based on the total amount of deposits held by a bank to total assets. This financial ratio shows in what measure the deposits attracted by the bank contribute to financing its assets (Roman \& Danuletiu, 2013). Relative to other liabilities deposit is the major source of funds for commercial banks, so incorporating deposit ratio in regression gives insight about the relationship between commercial banks profitability and this independent variable

\section{Funding Cost}

Proper management of expenses proves how efficient a bank is operating, that means by minimizing costs increasing profits is possible (Schipper IV, 2013). interest expenses to deposits ratio is one of the most focused on ratios at present it measures It is a gauge of efficiency while if the lending margins in a particular bank are extremely high then the ratio will improve as a result. It can be distorted by high net income from associates or volatile trading income (Hassan \& Bashir, 2002). The funding cost is considered as an internal explanatory variable given that it indicates how a bank's management is operationally cost efficient in managing the actions of the bank which will finally have an effect on the bank's profitability. This is for the reason that operating efficiency measures the cost of running a bank as a percentage of income so a high ratio of operating efficiency reflects that the management of the bank is operationally inefficient in controlling costs. This will ultimately have an adverse effect on the profitability of the bank (Rao \& Tekeste, 2012).

\section{Lending Interest Rate}

It is noticeable banks' profitability is pretentious to the difference between the lending rate and the interest with which they provide for depositors, which is the interest margin. Since both the lending rate and the interest rate on funding normally follow the policy rate. The low deposit rates together with high lending rate are not favorable for attracting savings. Then again somewhat high lending rates discourage borrowing by the productive sectors 
consequently dropping the growth of the economy so interest rates determine bank profitability. The funds raised by the bank from various sources are deployed in various assets. These assets yield income in the form of interest and the higher the interest the greater the profitability (Chinoda, 2014). A condition of low interest rates together with severe competition among banks could bound or limit the possibilities for banks to set proper prices for their loans and deposits, putting pressure on the operating margin and it will negatively affecting banks' profitability (Ponce, 2009).

\subsubsection{Macroeconomic Determinants}

Banks do not run their business in a separate tower rather somewhat in an economy where repeated fluctuations and general price movements are occurred (Katuka, 2015). As stated by Kutsienyo (2011) the surroundings in which banks operate can influence their strategic positioning and have impact on their profitability. The macroeconomic determinants correspond to actions outside the scope and control of the banks. These macroeconomic factors can be GDP, inflation, interest rate and others, they are external because the banks do not have control over them although banks can anticipate changes in the external environment and position themselves strategically to take advantage of them.

\section{Inflation}

Inflation is the rate at which the general level of prices for goods and services is rising. Inflation is well related with bank profitability; it entail high cost as more business operation and large branch network rise cost but also more revenue from bank float, this positive link depicts that bank's income increase with inflation more than bank cost (Driver, 2008).Inflation affects the real value of costs and revenues though it may have a positive or negative effect on profitability depending on whether it is expected or unexpected. In the case of expected inflation banks can timely adjust interest rates, which accordingly results in higher revenues than costs, with a positive impact on profitability. In the case of unexpected inflation banks may be slow in adjusting their interest rates resulting in a faster increase of bank costs than banks revenues as a result it will have a negative impact on bank profitability (Kosmidou et al., 2012). Thus properly predicting inflation gave banks a chance to adjust the interest rates accordingly and as a result to earn higher profits.

\section{Real Economic Growth Rate}

Real GDP growth rate is usually considered the key indicator of a countries standard of living. It depicts the position of the direction of the economic growth at a time. The ratio is usually figured as the GDP of the current year minus the GDP of the previous and divided by GDP of the previous year (Aminu, 2013). GDP is a measure of all the economic activity expected to have an effect on many factors related to the supply and demand for loans and deposits i.e. good economic conditions in the terms of growing economic activities, means increasing of household savings and demand of enterprises financing, which may have impact on banks profitability. According to Duraj \& Moci (2015) it is predictable that the relationship between GDP and banks profitability is positive. Unfavorable economic condition can worsen the quality of the loan collection that can create credit losses and increasing the provisions banks needs to hold, in this manner reducing bank profitability. On the other hand, good economic condition will improve the solvency of borrowers and increase demand for credit by household and firms that have positive effects on profitability of banks.

\section{Foreign Exchange Rate}

Exchange rates are quoted as foreign currency per unit of domestic currency or domestic currency per unit of foreign currency. Commercial banks and other depository institutions transactions involve buying/selling of bank deposits in more than one country currencies for investment (Krugman \& Obstfeld, 2004). It is one of the macroeconomic variables that might influence banks profitability; it may affect individual banks directly and/or indirectly. It directly affects the banks with their structure of assets and liabilities denominated in foreign currency. In contrast to the direct effect, the indirect effect of exchange rate deviation on the banks profitability, which principally originates from the effect of exchange variation on the businesses in general (Tadesse, 2015). As noted in National Bank of Ethiopia (2015/16) it is observable that from year to year Ethiopian birr is continuously depreciated relative to United States dollar, as a result of this in the current study the researcher use the value of annual average foreign exchange rate stated in terms of United States dollar. This variable is not covered as such other variables in the study of commercial banks profitability, even though there are some studies like Davydenko (2010) that can conclude the exchange rate has a positive significant effect on income which could be explained by the ability of banks managers to anticipate exchange rate fluctuations.

\section{Research Methodology}

\subsection{Research Design}

A research design can be defined as an arrangement of situations for collecting and analyzing of data in a manner that aims to combine relevance to the research purpose with efficiency in process. According to Bhattacherjee (2012) research designs are divided into two groups; positivist and interpretive based on how their objective in scientific research. In this study the researcher considered the positivist theories, which inquire about objective view of reality. From the various research designs explanatory is deemed to be appropriate and implemented in 
this study. The research approach in this study is quantitative, in which as stated by Marshal (1996) the goal of quantitative research is to test pre-determined hypotheses and produce general results. According to Creswell (2009) there are two major techniques of enquiry in quantitative approach like survey and experimental. In this study the researcher used survey, which is as stated by Zikmund, Babin, Carr \& Griffn (2009) non-experimental designs that do not control for or manipulate independent variables or treatments, but measure these variables and test their effects using statistical methods. The survey method permits the researcher to gather quantitative data which, helps to analyze quantitatively.

\subsection{Data Type, Source and analysis}

In this study the researcher used 17 commercial banks financial data, and NBE annual reports for subsequent 15 years, which covers the period from 2005-2019. Therefore, the study used published secondary data only. According to (Kothari, 1995) secondary data is a data that are already available. The collected data have the characteristics of both cross sectional and time series data, panel data. Panel data analysis is a method of studying an exacting subject within multiple sites, periodically observed over a defined time frame. The combination of time series with cross-section can improve the quality and quantity of data in ways that would be impossible using only one of these two dimensions (Gujarati, 2004). In this study all Ethiopian commercial banks are incorporated and the time period covers from 2005 - 2019. For the reason that all banks have a data more than five years and they are small in number (17). The other main reason to include all commercial banks exist in Ethiopia is that, it is not logical to infer about the total population by using none random sampling (Kothari, 1995). In this study the researcher carried out multiple regression analysis for the three dependent variable and ten explanatory variables. Regression analysis refers to the statistical testing of hypotheses (theory testing) (Bhattacherjee, 2012). The primary purpose of regression analysis is to make a judgment about a population, or the total collection of all elements about which a researcher seeks information (Zikmund et al., 2009). The collected bank specific and macroeconomic data was analyzed by using STATA version 14 econometrics software.

\subsection{Operational Definition of Variables}

\subsubsection{Dependent Variable}

- Return on Assets (ROA) - Return on asset is usually considered as a measure of profitability. It can be figured by dividing net income of the bank by the total asset. It shows what earnings have been produced from the invested capital or asset.

- Return on Equity (ROE) - it is also a measure of banks profitability in relation to equity. In our study ROE is measured as net income divided by shareholder's equity.

- Net Interest Margin - it the other variable that frequently used as a measure of commercial banks profitability so it is considered one of the dependent variable in our study. Interest revenue minus interest expense will be divided to total asset to compute the ratio of NIM.

\subsubsection{Independent Variables}

- Capital Adequacy (CA) - Capital adequacy ratio is frequently used as a measure of the financial strength of a bank or any financial institutions. The ratio in our study was figured by dividing the total capital to total assets of the bank.

- Bank Size (BS) - the researcher measured the bank size in terms of natural logarithm of banks total assets.

- Liquidity (LQ) - to measure the liquidity the researcher used the ratio of liquid assets (like; cash and short term receivables, short term securities and treasury bills) to total assets)

- Deposits ratio (DP) - it is computed as the ratio of total deposit that the bank collected to total asset.

- Credit Risk (CR) - is measured by the ratio of loan loss provisions to total loans.

- Funding Cost (FC) - It is estimated by the cost - to - income ratio and point towards how effectively bank's operating expenses are managed.

- Lending Interest Rate (IR) - the rate which Ethiopian commercial banks is used from the loan they grant. For this study annual average lending interest rate was used as a ratio

- Inflation (INF) - is the rate at which the general level of prices for goods and services is rising. For this study annual rate of inflation of the country was used.

- Economic Growth (EG) - It is typically considered the key pointer of a country's economic growth. It shows the level of productivity in the economy. The researcher used real GDP growth rate as a ratio.

- Foreign Exchange Rate (FER) -it is computing as foreign currency per unit of domestic currency or domestic currency per unit of foreign currency. For this study the researcher used annual weighted average exchange rate.

\subsection{Model Specification}

The study covers three dependent variables and ten explanatory or predictor variables, thus the model is multiple linear regression model. In order to choose the suitable econometric model (that maybe either fixed effect or 
random effect) the researcher conduct Hausman specification test. since at this stage the appropriate model is not known exactly, the composite error term is used as a residual. As we stated earlier our study incorporated 17 banks (cross sectional type) for the period 2005 - 2019 (time series type). For this data the following panel models are developed;

Fixed effect or Random effect;

$$
\begin{aligned}
& R O A_{i t}=\alpha_{i}+\beta_{1} C A_{i t}+\beta_{2} B S_{i t}+\beta_{3} L_{i t}+\beta_{4} D_{i t}+\beta_{5} C R_{i t}+\beta_{6} F C_{i t}+\beta_{7} R E G_{i t}+\beta_{8} I N F_{i t}+\beta_{9} L I R_{i t} \\
& +\beta_{10} F E R_{i t}+Y_{i t} \\
& R O E_{i t}=\alpha_{i}+\beta_{1} C A_{i t}+\beta_{2} B S_{i t}+\beta_{3} L_{i t}+\beta_{4} D_{i t}+\beta_{5} C R_{i t}+\beta_{6} F C_{i t}+\beta_{7} R E G_{i t}+\beta_{8} I N F_{i t}+\beta_{9} L I R_{i t} \\
& +\beta_{10} F E R_{i t}+Y_{i t} \\
& N I M_{i t}=\alpha_{i}+\beta_{1} C A_{i t}+\beta_{2} B S_{i t}+\beta_{3} L_{i t}+\beta_{4} D_{i t}+\beta_{5} C R_{i t}+\beta_{6} F C_{i t}+\beta_{7} R E G_{i t}+\beta_{8} I N F_{i t}+\beta_{9} L I R_{i t} \\
& +\beta_{10} F E R_{i t}+Y_{i t}
\end{aligned}
$$

\section{Result and Discussion}

In this chapter the researcher proceeds to describing the collected data, test the assumption of classical linear regression model, then analyze the effect of those explanatory variables (capital adequacy, bank size, deposit ratio, liquidity risk, credit risk, funding cost, real economic growth, inflation, interest rate and foreign exchange rate) to the dependent variable (return on asset), and in the last test early developed hypothesis based on the finding.

\subsection{Hausman Specification Test}

Hausman model specification test is a test used by researchers and scholars to select the appropriate model specification for panel data in between fixed effect model and random effect models. According to Hausman (1978) the null hypothesis is that the favored model is a random effect that assumes unobserved variables are uncorrelated; the alternative hypothesis is that the preferred model is fixed effect. In STATA if the alternative hypothesis is rejected that means if the Hausman specification tests shows the random effect is appropriate there should be one additional test (Breusch and Pagan Lagrangian multiplier test for random effects) to choose between the random effect and the simple ordinary list square (OLS) regression. But in Breusch and Pagan Lagrangian multiplier test for random effects the alternative hypothesis is that the preferred model is random effect and the null hypothesis is on the side of OLS regression. Therefore, the selecting criterion is straightforward if the "p"value is less than 0.05 , reject the null hypothesis or the fixed effect model is preferable than random effect. On the other hand, if " $p$ "- value is greater than 0.05 , a random effect model will be appropriate. To Breusch and Pagan Lagrangian multiplier test for random effects if the " $p$ "- value is less than 0.05 , random effect model is preferable than OLS regression. Alternatively, if " $p$ "- value is greater than 0.05 , a OLS regression can be used preferable. Below the STATA output for Hausman model specification test is presented to the three dependent variables.

Table: 4.1 Hausman specification test ROA

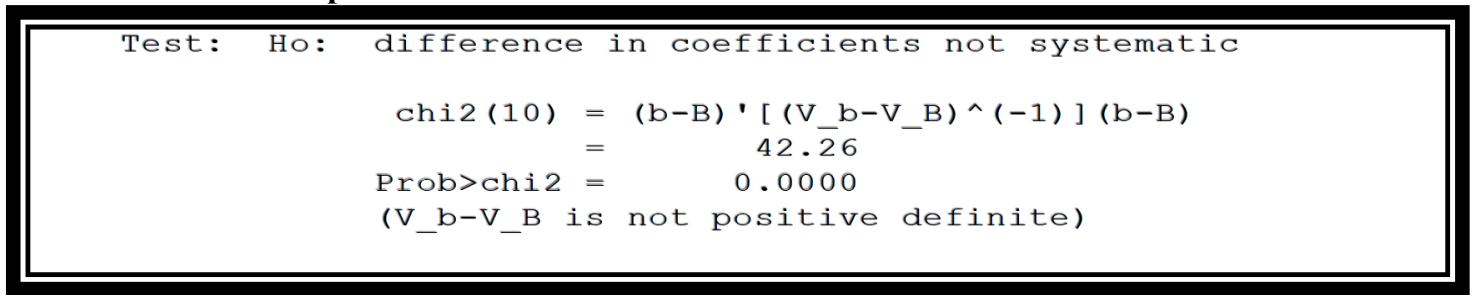

\section{Source: STATA 14 output for Hausman specification test for $R O A$}

As shown from the above table the value of " $p$ " is 0.0000 , less than the benchmark $(0.05)$ so, the null hypothesis of random effect is rejected and the alternative hypothesis of fixed effect model deemed to be appropriate for this study. So now the model is known and it can be stated as follow;

$$
\begin{gathered}
R O A_{i t}=\alpha_{i}+\beta_{1} C A_{i t}+\beta_{2} B S_{i t}+\beta_{3} L_{i t}+\beta_{4} D_{i t}+\beta_{5} C R_{i t}+\beta_{6} F C_{i t}+\beta_{7} R E G_{i t}+\beta_{8} I N F_{i t}+\beta_{9} L I R_{i t} \\
+\beta_{10} F E R_{i t}+\varepsilon_{i t}
\end{gathered}
$$

Table: 4.2 Hausman specification test for ROE

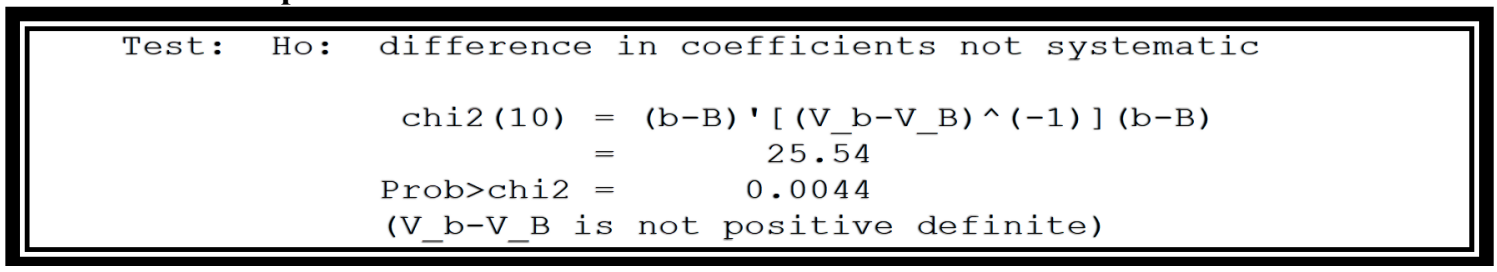

Source: STATA 14 output for Hausman specification test for ROE

Again for ROE dependent variable as clearly shown from the above table 4.2 the value of "p" is 0.0044 , less than the point of reference (0.05) so, the null hypothesis of random effect is rejected and the alternative hypothesis of fixed effect model deemed to be appropriate for the under study. The model for ROE is as the following; 


$$
\begin{gathered}
R O E_{i t}=\alpha_{i}+\beta_{1} C A_{i t}+\beta_{2} B S_{i t}+\beta_{3} L_{i t}+\beta_{4} D_{i t}+\beta_{5} C R_{i t}+\beta_{6} F C_{i t}+\beta_{7} R E G_{i t}+\beta_{8} I N F_{i t}+\beta_{9} L I R_{i t} \\
+\beta_{10} F E R_{i t}+\varepsilon_{i t}
\end{gathered}
$$

Table: 4.3 Hausman specification test for NIM

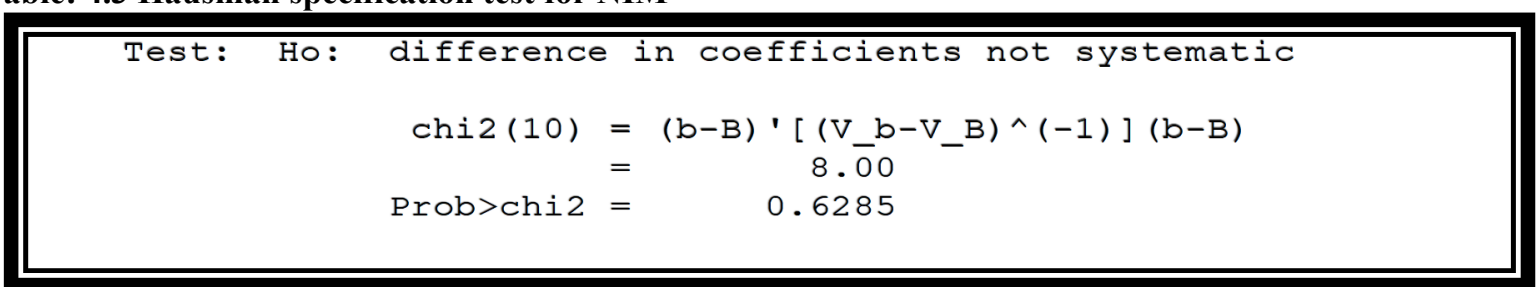

Source: STATA 14 output for Hausman specification test for NIM

On the other hand, the Hausman specification test for NIM is not just like that of ROA \& ROE. As shown from the above table 4.4 the value of " $p$ " is 0.6285 , which is fairly greater than the benchmark $(0.05)$ so, the alternative hypothesis of fixed effect is rejected and the null hypothesis of random effect model is selected, but one more additional test is mandatory to select between random effect and OLS regression, which is Breusch and Pagan Lagrangian multiplier test for random effects;

Table: 4.4 Breusch and Pagan Lagrangian multiplier test for random effects, NIM

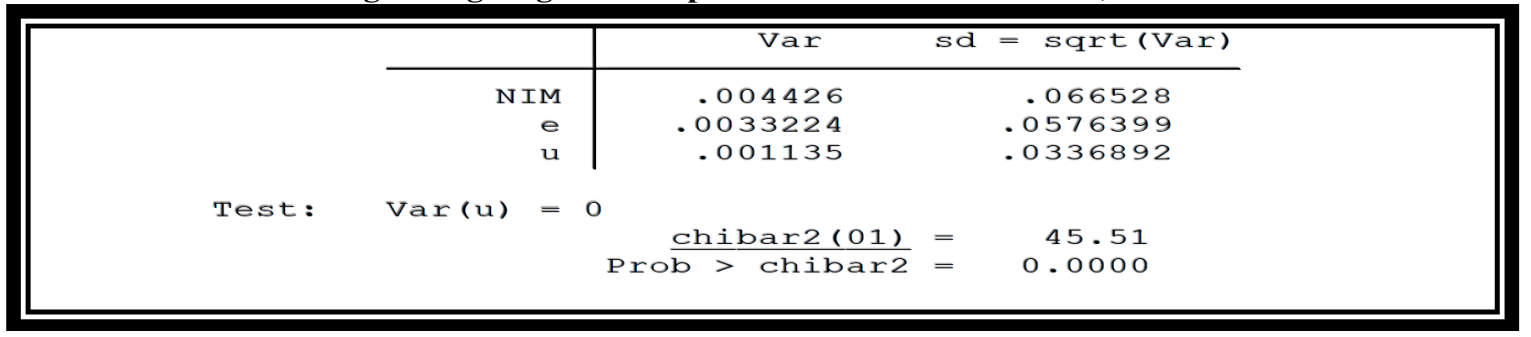

Source: STATA 14 output for Breusch and Pagan Lagrangian multiplier test for random effects.

From the table above 4.4 the researcher understand that the random effect model is appropriate that the simple ordinary list square regression model hence the STATA output for "p" value $(0.0000)$ is quite lower than the standard (0.05). Therefore, for NIM the following model is appropriate;

$$
\begin{gathered}
N I M_{i t}=\alpha_{i}+\beta_{1} C A_{i t}+\beta_{2} B S_{i t}+\beta_{3} L_{i t}+\beta_{4} D_{i t}+\beta_{5} C R_{i t}+\beta_{6} F C_{i t}+\beta_{7} R E G_{i t}+\beta_{8} I N F_{i t}+\beta_{9} L I R_{i t} \\
+\beta_{10} F E R_{i t}+\varepsilon_{i t}
\end{gathered}
$$

For fitting the classical linear regression model assumptions, particularly the assumptions of normality, serial correlation and heteroscedasticity, the above model is sated with transformation in to logarithmic value. The researcher generates both dependent and explanatory variables with log form. According to Wooldridge (2002) this model is termed as Log-Log Model. A regression model where the dependent variable and (at least some of) the explanatory variables are in logarithmic form.

\subsection{Regression Diagnostic Test}

In this study there are 3 dependent variables namely Return on Asset, Return on Equity and Net Interest Margin) and 10 explanatory variables categorized as bank specific industry specific and macro level variables namely Capital Adequacy, Bank Size, Liquidity, Deposit ratio, Credit Risk, Fund Cost, Inflation, Real Economic Growth, Foreign Exchange, and Lending interest rate). The data contains 15 years and 17 commercial banks exist in Ethiopia so called panel data. For this panel data the following classical linear regression diagnostics test is performed and the remedial action was taken accordingly in the regression analysis.

\subsubsection{Test for Normality}

From classical linear regression diagnostics test normality test is one of them. In STATA we can check the normality of a given data by using different methods like numerical methods and graphical distributions. From the numerical test Shapiro-Wilk W test for normality was used. According to Shapiro \& Wilk (1965) the nullhypothesis of the test is that the population is normally distributed. Accordingly, if the p-value generated from Shapiro-Wilk W for the error terms or residual is less than the chosen significant level (5\%), then the null hypothesis is rejected and there is evidence that the data tested are not from a normally distributed population. Quite the reverse, if the p-value generated from Shapiro-Wilk W for the residual is greater than the chosen significance level, the null hypothesis that the data came from a normally distributed population cannot be rejected. Here under the STATA 14 output is presented for the three dependent variable error terms.

Table 4.5: Test for normality of residuals, ROA.

\begin{tabular}{|l|ll|l|l|l|}
\hline Variable & Obs & W & V & Z & Prob $>$ Z \\
\hline Residual & 195 & 0.98246 & 1.560 & 2.160 & 0.01538 \\
\hline
\end{tabular}

Source: STATA 14 output, Shapiro-Wilk W test for normality test 
Table 4.6: Test for normality of residuals, ROE.

\begin{tabular}{|l|ll|l|l|l|}
\hline Variable & Obs & W & V & z & Prob $>$ z \\
\hline Residual & 195 & 0.9973 & 2.8583 & 2.331 & 0.1393 \\
\hline
\end{tabular}

Source: STATA 14 output, Shapiro-Wilk $W$ test for normality test

Table 4.7: Test for normality of residuals, NIM.

\begin{tabular}{|l|ll|l|l|l|}
\hline Variable & Obs & W & V & Z & Prob $>\mathrm{Z}$ \\
\hline Residual & 195 & 0.12477 & 1.560 & 1.058 & 0.0000 \\
\hline
\end{tabular}

Source: STATA 14 output, Shapiro-Wilk $W$ test for normality test

As shown from the above table the error term with the exception of residuals for Return on Equity, the data collected is not normally distributed, meanwhile the p value for residual of NIM (0.000) and ROA (0.01538) is less than the significant level there should be a remedial action to get actual effect of the selected explanatory variables on those two dependent variables. In this case there are two ways to deal with error terms that are not normally distributed. The first method is transformation of the data that means performing similar mathematical operation on each dependent and explanatory variable. The operation can be squared root, logarithmic or others, multiplication or dividing all ratios with the same amount. The second one is Bootstrapping or Bootstrap estimation, which is an option to produce bias-corrected confidence intervals around the coefficients. For this study regarding to Return on Asset Regression Bootstrapping estimation was used as a remedial action. On the other hand, for Net Interest Margin regression transforming to logarithmic value of the original data for NIM and all other explanatory variables is done, this is because in NIM it is impossible to apply Bootstrap estimation because it has also some other regression diagnostic test problems like Autocorrelation \& heteroscedasticity discussed on the subsequent section.

\subsubsection{Test for Autocorrelation}

Serial correlation or Autocorrelation is happened when there is a significant relationship between error terms or residuals in different time periods under study, it can be occurred in a time series or panel data model (Wooldridge, 2002). According to Durbin \& Watson test for serial correlation the null hypothesis that the error terms from an ordinary least-squares regression with different time period have no correlated in contradiction of the alternative hypothesis that the residuals follow an AR1 process. The Durbin-Watson statistic contains value from zero to four. For this study the three dependent variables are tested separately by using the Durbin-Watson d statistics table for $\mathrm{n}=195$ observations and $\mathrm{k}=11$ is the number of regressors exclusive of the intercept was taken at $5 \%$ level of significance. The critical value for lower limit and upper limit of ROA was $1.579 \& 1.892$ respectively. From the regression output computed in STATA 14 software the value of Durbin-Watson d-statistic $(11,195)$ is given as 1.7594. therefore, this value is in between the upper and lower bounds it can be said that it is inconclusive so no serial correlation of error terms was found in ROA. On the other hand, the test for autocorrelation to ROE and NIM were not good as such ROA. Durbin-Watson d-statistic for ROE found as $(11,195)=1.476526$ and regarding to NIM the STATA output shows $(11,195)=1.5139$. for a data that have autocorrelations problems the are some remedial actions like Robust method and Prais - Winsten regression, Correlated Panel Correlated Standard Error (PCSEs). So the later method was used as a remedial action in regressing ROE and NIM.

\subsubsection{Heteroscedasticity}

According to Wooldridge (2002) heteroscedasticity will happen when the variance of the error term (residual), considering the explanatory variables, is not constant. For this study Breusch - Pagan Test, a test for heteroscedasticity, where the residual square is regressed on the predictor variables in the model is used. According Breusch \& Pagan (1979) from the regression output if the test statistic has a p - value below an appropriate significant level (in this study 5\%) then the null hypothesis of homoscedasticity is rejected and heteroscedasticity is presumed. Alternatively, if $\mathrm{p}$ - value is greater than 5\%(0.05), homoscedasticity or no heteroscedasticity problem is considered. STATA 14 output for heteroscedasticity test regression shows Prob $>$ chi2 value of residual square for ROA, ROE \& NIM are 0.0682, $0.2157 \& 0.0059$ respectively. And the standard sated by Breusch \& Pagan (1979) is 0.05 . Therefore, it can be concluded that there is no heteroscedasticity problem for ROA \& ROE. On the other hand, the result of heteroscedasticity test for NIM is not good 0.0059 that is lower than the standard, which means there is a significant relationship between the squared residual and explanatory variables. As a result, for this study robust method and transformation of the data to logarithmic value were used to solve this diagnostic test problem.

\subsubsection{Multi - collinearity Test}

According to Wooldridge (2002) multi - collinearity is a significant relationship between explanatory variables in a multiple regression model; it is usually happened when some correlations are large, but an actual magnitude is not well-defined. If there is a perfect melticollinearity in a given explanatory variable, then the correlation matrix for those variables will be 1 . In this case dropping one variable is advisable. As noted by Kennedy (2008) if the correlation coefficient for explanatory variables is more than 0.80 , then multi-collinearity problem may be existed. 
As shown from the following Pearson Pair wise correlation matrix there are some indicators to say there is multicollinearity problems between lending interest rate and real economic growth $(0.7997) \&$ between lending interest rate and foreign exchange rate $(0.8760)$, which is the highest correlation matrix between explanatory variables. So in this situation one additional test is performed known as the variance inflation factor. According to Gujarati (2004) if VIF has a value of 10 and above it can be said that there is a problem of multi-collinearity. In this study the value of mean Variance Inflation Factor (VIF) is 3.55, which is tolerable collinearity among explanatory variables because it is less than the rule of thumb (10).

\section{Table: 4.12 Correlation matrixes}

\begin{tabular}{|c|c|c|c|c|c|c|c|c|c|c|c|c|}
\hline & ROA & ROE NIM & CA & $\mathrm{BS}$ & $\mathrm{D}$ & $\mathrm{L} \mathrm{CR}$ & $\mathrm{FC}$ & INF & REG & FER & LIR & \\
\hline ROA & 1.0000 & & & & & & & & & & & \\
\hline $\mathrm{ROE}$ & 0.2591 & 1.0000 & & & & & & & & & & \\
\hline NIM & 0.0051 & -0.0704 & 1.0000 & & & & & & & & & \\
\hline $\mathrm{CA}$ & 0.1055 & -0.5702 & 0.0103 & 1.0000 & & & & & & & & \\
\hline $\mathrm{BS}$ & 0.0010 & 0.4518 & -0.1581 & -0.6275 & 1.0000 & & & & & & & \\
\hline $\mathrm{D}$ & -0.2083 & 0.2348 & 0.0254 & -0.6912 & 0.3814 & 1.0000 & & & & & & \\
\hline L-0.0809 & 0.0082 & -0.0457 & 0.0867 & -0.4383 & -0.2082 & 1.0000 & & & & & & \\
\hline $\mathrm{CR}$ & -0.1142 & 0.2144 & 0.0425 & -0.3228 & 0.3266 & 0.1491 & 0.0440 & 1.0000 & & & & \\
\hline $\mathrm{FC}$ & 0.0252 & -0.1815 & -0.0705 & 0.2270 & 0.0456 & 0.0375 & -0.4362 & -0.1964 & 1.0000 & & & \\
\hline INF & -0.0469 & -0.0314 & -0.0775 & 0.0519 & -0.1019 & -0.1676 & 0.2505 & -0.1277 & -0.1315 & 1.0000 & & \\
\hline REG & 0.0039 & 0.1424 & 0.1934 & -0.1310 & -0.3028 & 0.0423 & 0.4440 & 0.2124 & -0.4318 & -0.1183 & 1.0000 & \\
\hline FER & 0.0806 & -0.1154 & -0.1407 & 0.1198 & 0.4147 & 0.0745 & -0.6608 & -0.1311 & 0.6033 & -0.2336 & -0.7124 & 1.0000 \\
\hline LIR & 0.0053 & -0.1631 & -0.1943 & 0.0860 & 0.4018 & 0.0625 & -0.4432 & 0.1861 & 0.5304 & -0.0638 & -0.7997 & 0.87601 .0000 \\
\hline
\end{tabular}

Source: STATA 14 output for Pearson Correlation Matrix

\subsection{Regression Results and Discussions}

This section presents the results of fixed effect model regression and discussions for the determinants of profitability, which covers one dependent variable (Return on Asset) and nine explanatory variables (Capital Adequacy, Bank Size, Liquidity Risk, Credit Risk, Operations Efficiency, Lending Interest Rate. Inflation Rate, Real GDP Growth Rate, and Foreign Exchange Rate.

\subsubsection{Regression Result}

\section{Table: 4.14 Regression Analyses for ROA}

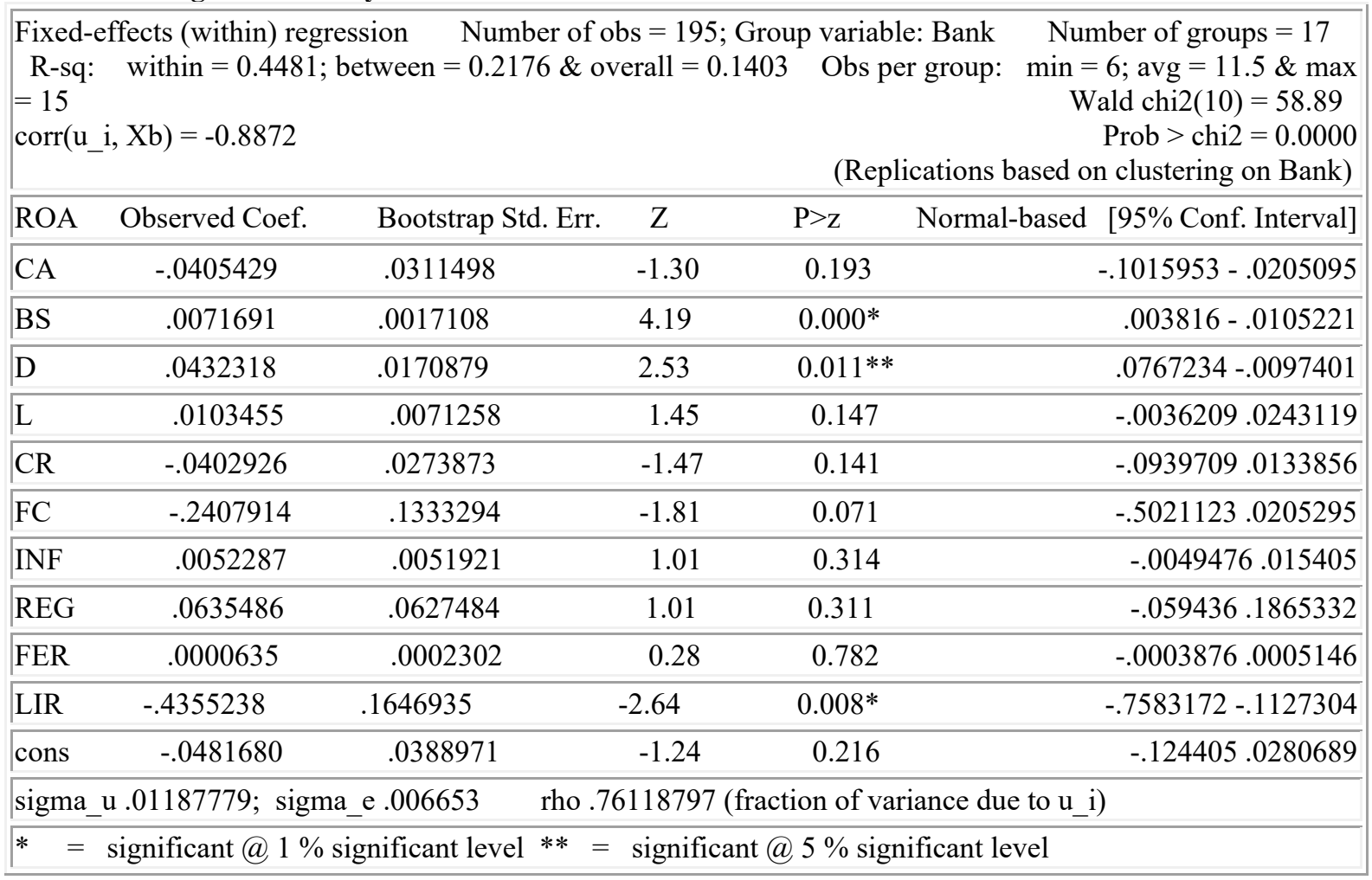

Source: STATA 14 output for fixed effect regression analyses for ROA. 
Table: 4.15 Regression Analyses for ROE

Prais-Winsten regression, correlated panels corrected standard errors (PCSEs)

Group variable: Bank; Time variable: Year. Panels: correlated (unbalanced) Autocorrelation: common AR(1) Sigma computed by case wise selection. Estimated covariances $=153$; Estimated autocorrelations $=1$; Estimated; coefficients $=11$. Number of obs $=195$. Number of groups $=17$. Obs per group: $\min =6 ;$ avg $=11.470588 ; \max =15$.

R-squared $=0.5183 ;$ Wald chi2 $(10)=57.44 ;$ Prob $>$ chi $2=0.0000$

\begin{tabular}{|lccccr|}
\hline ROE & Coef. & Panel-corrected Std. Err. & $\mathrm{z}$ & $\mathrm{P}>\mathrm{z}$ & [95\% Conf. Interval] \\
\hline CA & 1.008784 & .3776792 & 2.67 & $0.008^{*}$ & $1.749022-.2685467$ \\
\hline BS & .042749 & .0183234 & 2.33 & $0.020 * *$ & .0068359 .0786621 \\
\hline D & -.1974501 & .2751181 & -0.72 & 0.473 & -.7366717 .3417714 \\
\hline L & .2153073 & .1468432 & 1.47 & 0.143 & -.0725001 .5031147 \\
\hline CR & -.9209807 & .7669533 & -1.20 & 0.230 & -2.424182 .5822203 \\
\hline FC & .2493583 & 1.380271 & 0.18 & 0.857 & -2.4559232 .95464 \\
\hline INF & -.0165313 & .0720825 & -0.23 & 0.819 & -.1578103 .1247478 \\
\hline REG & -.5739832 & .6971603 & -0.82 & 0.410 & -1.940392 .7924258 \\
\hline FER & .0062886 & .0041193 & 1.53 & 0.127 & -.001785 .0143623 \\
\hline LIR & -8.339369 & 2.735853 & -3.05 & $0.002 *$ & $-13.70154-2.977195$ \\
\hline Cons & .4605719 & .5143218 & 0.90 & 0.371 & -.54748031 .468624 \\
\hline rho .2969932 & $*$ & significant @ $1 \%$ significant level & $* *$ & $=$ & significant @ 5 \% significant level \\
\hline
\end{tabular}

Source: STATA 14 output for fixed effect regression analyses for

Table: 4.16 Regression Analyses for NIM

Prais-Winsten regression, correlated panels corrected standard errors (PCSEs)

Group variable: Bank; Time variable: Year. Panels: correlated (unbalanced); Autocorrelation: common AR(1) Sigma computed by case wise selection. Estimated covariances $=153$; Estimated autocorrelations = 1; Estimated; coefficients $=11$. Number of obs $=195$. Number of groups $=17$. Obs per group: $\min =6 ;$ avg $=11.470588 ; \max =15$.

R-squared $=0.5437 ;$ Wald $\operatorname{chi} 2(10)=44.47 ;$ Prob $>$ chi2 $=0.0000$

\begin{tabular}{|c|c|c|c|c|c|}
\hline $\operatorname{logNIM}$ & Coef. & Panel-corrected Std. Err. & $\mathrm{Z}$ & $\mathrm{P}>\mathrm{Z}$ & [95\% Conf. Interval] \\
\hline $\log \mathrm{CA}$ & .1375939 & .1299686 & 1.06 & 0.290 & $-.1171399-.3923277$ \\
\hline $\log B S$ & -2.124347 & .9242557 & -2.30 & $0.022 * *$ & $-3.935855-.3128394$ \\
\hline $\log \mathrm{D}$ & 1.463088 & .3257681 & 4.49 & $0.000 *$ & $.8245937-2.101581$ \\
\hline $\log \mathrm{L}$ & -.4004805 & .0857035 & -4.67 & $0.000 *$ & $-.5684563-.2325047$ \\
\hline $\log C R$ & -.0303994 & .0209137 & -1.45 & 0.146 & $-.0713895-.0105907$ \\
\hline $\operatorname{logFC}$ & -.0658491 & .0878553 & -0.75 & 0.454 & $-.2380423-.1063441$ \\
\hline $\log I N F$ & .0011786 & .0319019 & 0.04 & 0.971 & $-.0613479-.0637051$ \\
\hline $\log R E G$ & .0095827 & .2122647 & 0.05 & 0.964 & $-.4064484-.4256139$ \\
\hline $\operatorname{logFER}$ & -.2353353 & .1677526 & -1.40 & 0.161 & $-.5641242-.0934537$ \\
\hline $\log \mathrm{LIR}$ & .5697432 & .8449771 & 0.67 & 0.500 & $-1.086382-2.225868$ \\
\hline Cons & 5.301685 & 3.862116 & 1.37 & 0.170 & $-2.267923-12.87129$ \\
\hline
\end{tabular}

rho $.4733 \quad *=$ significant @ $1 \%$ significant level $* *=$ significant @ $5 \%$ significant level

Source: STATA 14 output for fixed effect regression analyses for NIM.

\subsubsection{Discussion}

Here regarding to the first (ROA) dependent variable as shown in the above table the Bootstrap Normale Based Fixed-effects regression, for the second dependent variable (ROE) Prais-Winsten Regression, Correlated Panels Corrected Standard Errors (PCSEs), \& for the third variable (NIM) PCSEs with log value regressions are conducted by using unbalanced data set of 195 observations, which is collected from 17 commercial banks exist in Ethiopia at the study period from the year 2005 to 2019 with a minimum year taken (6 years) for lately 
established banks and a maximum year ( 15 years) for early established banks. From the above the tables the value of "Prob > chi2" for ROA, ROE \& NIM are 0.0000 . So it can be possible to say this study model is better explained by the independent variable regressed. This is a means to see whether all the coefficients in the model are different than zero. Again in table 4.13, 4.14 \& 4.15, Coef., denotes the coefficients of explanatory variables that indicates how much dependent variable changes when the independent variable increases by one percent. 'rho' in indicates the variance is due to differences across panels, so the variation shows $76.12 \%, 29.69 \% \& 46.33 \%$ for ROA, ROE $\&$ NIM respectively. The value of R square $(44.81 \%$ for ROA, $51.83 \%$ for ROE \& 54.37 for NIM) in the above table indicates the variation of dependent variable due to the change in explanatory variables involved in this study. The two-tail p-values sows that the significant levels in our study at 95 confidence level. Relative to the other dependent variables NIM is most explained by the overserved explanatory variable. If the p-value has to be lower than $5 \%$ or 0.05 then it can be said that the variable has a significant influence on the dependent variable. Similarly, it can be possible to understand the significance of explanatory variables by considering "Z" value. If the value for " $Z$ " is greater than 1.96 for $95 \%$ confidence level it is possible to say the independent variable is significantly influence the dependent variables. By considering the above stated benchmarks and some selected empirical researches the following discussions are accompanied.

The first bank specific variable is Capital Adequacy (CA), which is a measure of capital strength of banks and a significant explanatory variable with a $\mathrm{p}$ - value of 0.008 (at $1 \%$ ) if a bank's profitability is measured as ROE. But it is insignificant when a profitability of banks is measured by using ROA \& NIM. Some researchers like Ani \& et al. (2012); Samuel (2015); Obamuyi (2013) and Habtamu (2012), found a positive significant relationship between capital adequacy and banks profitability. The Coefficients of capital adequacy is -1.008784 , that means a $1 \%$ change in a capital adequacy of a bank will have a positive $1 \%$ influence on commercial banks profitability (ROE). As stated in the above paragraph the relationship of CA and ROE is positive and significant. Therefore, increasing stockholders' equity section of banks will create a sustainable profit. It is obvious that banks with higher equity to total asset ratio can make an efficient intermediation practice, create large amount of loans to their customers and make expansion of their service easily. In general, the result of this study is in consistence with various other studies conducted in this area. And it is not surprising because banks with higher capital strength will generate a higher profitability, so the result is in line with early expectation.

The other bank specific explanatory variable in this study is bank size, which is measured as natural logarithm of banks total asset. As shown in the regression result bank size is significant explanatory variable for all measures of commercial banks profitability with a ' $p$ ' value of $0.000,0.0200 .022$ for ROA, ROE and NIM respectively. So it is possible to say the effect of bank size on ROA, ROE and NIM is significant at $1 \%, 5 \%$ \& 5\% significant level. The coefficient of bank size on the three dependent variable is 0.0071691 for ROA, 0.042749 for ROE \& -2.124347 for NIM. The coefficient indicates bank size has positive effect on banks profitability if the measure is ROA \& ROE. On the other hand, if commercial banks profitability is measured by NIM the effect out to be negative. It is clear to notice that the relevance of bank size for banks profitability since the regression result shows for all dependent variables bank size has significant effect. Other researchers like Tsalkitzidis (2011); Samuel (2015); Obamuyi (2013) and Habtamu (2012), who found significant and positive relationship between bank size and profitability that are in line with our study if the measure is ROA \& ROE. Even though most litratures found stasticaly signficant and positve relationship between commercial banks total asset and profitability, some different results are recorded. For instance the studies of Hoffmann (2011) and Ani et al.(2012) found bank size have negative and significant effect on profitability that is consistent with our study if a measure is NIM. When we look for ROA ROE this study result also in line with the basic theory, which is large banks are more profitable than small banks due to their ability to diversify and reduce risk. So it is possible to say commercial banks with higher total asset will generate higher profitability compared to other commercial banks. Ethiopian commercial banks have economies of scale that means citrus paribus with increasing banking service or expanding they can increase their profitability.

As per the regression result the deposit ratio that is computed as total deposit divided by total asset is an important explanatory variable for Ethiopian commercial banks profitability since the ' $p$ ' for Deposit is 0.0000 to NIM and 0.011 to ROA. So this explanatory variable has significant influence at $1 \%$ and $5 \%$ significant level on NIM and ROA respectively. The coefficient of Deposit shows 1.463088 for NIM \& 0.0432318 for ROA, since the coefficient values has a positive sign it is possible to say that the relationship between Ethiopian commercial banks profitability, which is measured by ROA \& NIM, is positive and significant. From the coefficient it can be conclude that if an increase in the ratio of deposit by $1 \%$ will lead the commercial banks profitability with 1.463088 if the measure is NIM and with 0.0432318 if the measurement of banks profitability converted to ROA. The result is expected and consistence with the outcome of some researchers like Roman \& Danuletiu (2013). Again it is obvious as the banks major activity is mobilization of resources by collecting funds from depositor and providing it to those who are in need, collecting huge amount of deposits can lead the commercial bank to a sustinable profite.

Liquidity is taken in this study as the ratio of banks total loan to total asset. The result for this study shows a' p' value of $0.147,0.143 \& 0.000$ for ROA, ROE \& NIM respectively. And a coefficient of $0.0103455,0.2153073$ 
\& -0.4004805 for ROA, ROE \& NIM respectively. So liquidity is highly significant (at $1 \%$ level of significance) and negative effect on commercial banks profitability if it is measured by NIM but if the measure is changed to ROA or ROE it out to be insignificant. Since the 'p' value of liquidity is not considerably high for the ROA and ROE, and it shows a significant negative influence on NIM this variable should be considered as an important explanatory variable for Ethiopian commercial banks. So regarding to NIM and Liquidity, one percent increase in Ethiopian commercial banks liquidity will have -0.4004805 percent decrease in profitability. That means holding other variables constant increasing total loans without considering available asset will decrease Ethiopian commercial banks profitability. Most literature like Ayadi \& Boujelbene (2012); and Samuel (2015) found negative relationship regarding to commercial banks profitability and liquidity. So the result of this study is consistence with various empirical studies and also it is in line with the basic theory, which states that there is a tradeoff between profitability and liquidity.

The other bank specific variable included in this study is credit risk, which is computed as the ratio of provisions for loans and advances to total loans with a ' $p$ ' value of $0.141,0.230 \& 0.146$ for ROA, ROE \& NIM respectively. Credit risk in all dependent variables credit risk has a negative and statistically insignificant relationship. Actually the reason behind this result is that in Ethiopian commercial banks relative to the loan they provide the value of loan loss provision is immaterial even in some commercial banks it has a zero value for some years. No supporting empirical study is found with this study results, researcher like Athanasoglou et al. (2005) found credit risk variable (CR) is negatively and significantly related to bank profitability again Nisar et al. (2015) found Credit Risk as measured by non-performing loans to gross advances has shown negative and highly significant sign. Also a study conducted in Ethiopia by Rao \& Tekeste (2012) found that the sign of loan loss reserve to total loans, which measures bank's credit risk, is negative. But similar to liquidity risk this study result for credit risk is supported by the basic risk return tradeoff theory.

Similar to credit risk explanatory variable funding cost has insignificant effect on the determination of Ethiopian commercial banks profitability with a 'p' value of $0.071,0.857 \& 0.454$ for ROA, ROE \& NIM respectively. The coefficients of funding cost have a negative direction in the effect of Ethiopian commercial banks profitability with a value of -.0658491 (NIM) and 0.0658491 (ROE) and if the consideration is changed to ROA the effect of funding cost can be positive 0.2493583 (ROA).

In this study lending interest rate is the only one variable selected from the industry specific explanatory variables. It is obvious that the largest commercial banks income is collected from interest revenues, annual average lending interest rate of Ethiopian commercial banks is used as a ratio to measure this variable. The result from the above bootstrap regression for ROA and PSCEs regression of ROE shows lending interest rate is statistically significant with $\mathrm{p}$ - value of 0.008 and 0.002 respectively that means at $1 \%$ level of significant. Surprisingly the coefficient for this industry specific explanatory variable is for ROA -0.4355238 and ROE 8.339369. This from this result it is possible to conclude that citrus paribus a 1 percent increase in Ethiopian commercial banks LIR will diminish the ratio of ROA by -0.4355238 and ROE by -8.339369 . According to Yalemselam (2019) it can be happed as a reason, if lending interest rate goes higher and higher, the number of borrower will have reduced and enough amount of interest revenue will not be collected. The result for this study is different from other studies result. The empirical findings of Saeed (2014) indicate a strong positive relationship of real interest rate with ROA. Similarly, the study of Haron (2004) found that interest rate has a positive relationship with total income received by Islamic banks. In general, on the contrary as per this study increasing above the current lending interest rate in Ethiopian commercial banks will have an adverse consequence for their profitability.

The three macroeconomic explanatory variables (Inflation Rate, Real economic growth and Foreign exchange rate) have no significant influence on the determination of Ethiopian commercial banks profitability because the regression result of this study shows a ' $p$ ' of more than 0.05 in all dependent variables (ROA, ROE \& NIM); inflation has $0.341,0.819 \& 0.971$ ' $p$ ' values on ROA ROE \& NIM; REG have a ' $p$ ' values $0.311,0.410$ \& 0.964 on ROA ROE \& NIM respectively; similarly FER has a 'p' value of 0.121 for ROA, 0.167 for ROE \& 0.788 for NIM. the result of these variables found not as expected as well as consistent with other studies like Boitan (2014) who found positive significant relationship between banks profitability and economic growth. The study of Davydenko (2010) found that foreign exchange rate has a positive significant effect on income which could be explained by the ability of banks managers to anticipate exchange rate fluctuations which is not consistent with our study in its significance but there is a similarity on the direction of the effect. All in all, it is possible to say that in this study the effect of macro - economic explanatory variables have a positive but not significant influence on Ethiopian commercial banks profitability.

\section{Summary of Finding, Conclusion and Recommendation}

The final chapter of this study is chapter five, which is about summary, conclusion and recommendation of the study. In view of that this chapter is organized with four sections. The first section summarizes the main findings of the study; the second section presents the conclusion whereas the third section presents the recommendations 
and finally room for further study is presented.

\subsection{Summary of finding \& conclusion}

Commercial Banks, as the main part of financial system, play an important role in contributing to a country's economic development. So understanding factors affecting commercial banks profitability is essential, since profitability is the base for existence in the business. The objective of this study is investigating factors that determine the profitability of Ethiopian private commercial banks under the study period, which covered fifteen years period $(2005$ - 2019). In this study there are three dependent variables (ROA, ROE \& NIM) and ten explanatory Variables that are classified in to three groups; bank specific (capital adequacy, bank size, liquidity risk, credit risk \& funding cost), external or macroeconomic factors (inflation rate, real economic growth rate, and foreign exchange rate) and industry specific (lending interest rate).

The data for this study was collected from 17 Ethiopian commercial banks audited financial statement for bank specific explanatory and dependent variables, and macroeconomic explanatory variables are collected in National Bank of Ethiopia Annual Report. After collecting the necessary data from the above listed source, the researcher summarizes the data to depict (and compare) variables numerically and enable researchers to organize, summarize, and describe observations. Then after Hausman model specification test was used to select the appropriate model. The model specification test for ROA \& ROE shows fixed effect model is appropriate on the other hand, NIM was best accorded with random effect model. Regression diagnostic test is conducted to identify whether the data is fit classical linear regression model assumptions. In doing this there was normality assumption problem in ROA \& NIM, autocorrelation problem in NIM \& ROE and heteroscedasticity problem in NIM. Therefore, transformation of the data to logarithmic and PCSEs regression was used as a remedial action to NIM. On the other hand, to generate normal based confidence interval bootstrap regression was used for ROA. Regarding to ROE to handle the autocorrelation problem PCSEs regression was applied.

Finally, the regression result shows; Capital adequacy is a significant explanatory variable at $1 \%$ and correlated positively if a bank's profitability is measured as ROE. But it is insignificant when a profitability of banks is measured by using ROA \& NIM. Bank Size is an explanatory variable incorporated in this study, which is the best determining variable in the determination of banks profitability in all dependent variable measurement circumstance. The result of bootstrap regression for ROA and PSCEs regression of ROE shows Bank Size is correlated positively with ROA \& ROE at $1 \%$ \& $5 \%$ significant level respectively. But the relationship between Bank Size and NIM was negative and significant at 5\%. Deposit Ratio that is an important explanatory variable in the determination of Ethiopian commercial banks profitability since it has a positive and significant relationship with ROA \& NIM at 5\% \& $1 \%$ level of significant respectively. The other bank specific explanatory variable; liquidity is highly significant (at $1 \%$ level of significance) and has a negative effect on commercial banks profitability if it is measured by NIM, but if the measure is changed to ROA or ROE it out to be insignificant. On the other hand, the last two explanatory variables have no a significant influence in the Ethiopian commercial banks profitability measured as ROA, ROE \& NIM. The result for lending interest rate (the only one variable selected from industry specific explanatory variables) is statistically significant and negatively correlated with ROA \& ROE at $1 \%$ level of significant. Surprisingly all the macro-economic variables (Inflation Rate, Real Economic Growth Rate \& Foreign Exchange Rate) incorporated in this study were not a significant variable in the determination of Ethiopian commercial banks profitability.

\subsection{Recommendation}

From the 17 Ethiopian commercial banks the researcher selected 3 dependent variables and 10 explanatory variables categorized in to three groups and the selected data is organized tested and analyzed by using STATA 14 both in inferential statics and descriptive statistics. So according to the findings of this study the following recommendations are given to the concerned bodies;

From the finding one of the bank specific explanatory variable is capital adequacy. The relationship between Ethiopian commercial banks profitability (measured by ROE) and capital adequacy is positive and significant. Considering this Ethiopian commercial banks should increase their equity by issuing new stocks, retaining the annual income in the bank and by other means that can boost their capital correspondingly their profit will increase.

The other important bank specific explanatory variable is bank size. Which is highly correlated with Ethiopian commercial banks profitability and it has a positive effect. so expansions like horizontal integrations \& opening branches in different area have a positive effect on Ethiopian commercial banks profitability. Similarly, since the bank size is measured by total assets of a bank any activity that can increase the total asset can also increase profitability.

The explanatory variable Deposit Ratio have a positive significant effect on the determination of commercial banks profitability so collecting large amount of deposit in different type can lead commercial banks to a sustainable profit. It is obvious increasing deposit is one of the mechanism to increasing total asset so these two variables indicate increasing the size of Ethiopian commercial banks has undeniable effect to boost profit. 
The fourth bank specific explanatory variable liquidity which is measured by the ratio of most liquid assets (like cash, short term treasury bills and short term receivables) to total assets. Liquidity and Ethiopian banks profitability is negatively related. Therefore, holding higher liquid assets without investment or providing loans to prudent customers will lead the bank to continues profit deterioration. To handle this problem Ethiopian commercial banks, have to consider the ratio of liquid asset to total asset in their decision making.

The last significant explanatory variable is the industry specific variable of Lending Interest Rate which has a negative effect on Ethiopian commercial banks profitability. So according to the finding of this study farther increment on the interest rate of loan will diminish banks profitability. Therefore, increasing Lending Interest Rate is not advisable to Ethiopian commercial banks profitability.

\section{Bibliography}

Abreha, G. (2015). Determinants of Bank Sector Development in Ethiopia. Addis Ababa University, Addis Ababa, Ethiopia.

Adeusi, S. O., Aluko, A. O., \& Klapo, F. J. (2014, December). Determinants of Commercial Banks Profitability Panel Evidence from Nigeria. International Journal of Economics, Commerce and Management, 11(12), 118.

Alzorqan, S. T. (2014). Bank Liquidity Risk and Performance: An Empirical Study of the Banking System in Jordan. Research Journal of Finance and Accounting, 5, 155-165.

Aminu, A. B. (2013). The Determinants Of Bank's Profitability in Nigeria. Msc, Eastern Mediterranean University, Gazimagusa, North Cyprus.

Ani, W. U., Ugwunta, D. O., Ezeudu, I. J., \& Ugwuanyi, G. O. (2012, December). An empirical assessment of the determinants of bank profitability in Nigeria: Bank characteristics panel evidence. Journal of Accounting and Taxation, 4(3), 38-43.

Athanasoglou, P. P., Brissimis, S. N., \& Delis, M. D. (2005). Bank spacific, Indestry spasific and macroeconomic determinants of bank profitability. Greece.

Ayadi, N., \& Boujelbene, Y. (2012). The Determinants of the Profitability of The Runidian Deposit Banks. University de Sfax. Tunisie: IBIMA Publishing.

Béjaoui, R., \& Bouzgarrou, H. (2014). DETERMINANTS OF TUNISIAN BANK PROFITABILITY. The International Journal of Business and Finance Research, 8, 121 - 132.

Bhattacherjee, A. (2012). Social Science Research: Principles, Methods, and Practices. University of South Florida.

Boitan, L. A. (2014, November 14). Determinants of Sustainable Banks Profitability Evidence from Europian Union Countries. Financial studies, 21-39.

Bojaoui, R., \& Bouzgarrou, H. (2014). Determinants of Tunisian banks Profitability. International journal of business and Finance Research, 8(4), 121-131.

Cekrizi, A. (2015). Factors affecting performance of commercial banks in Albania. University of A.Xhuvani, Elbasan, Albania.

Chinoda, T. (2014, December). The Determinants of Commercial Banks Profitability in Zimbabwe (2009-2014). IOSR Journal of Economics and Finance, 5(6), 69-80.

Creswell, J. W. (2009). Research design: Qualitative, quantitative, and mixed methods approaches. New York: Sage Publication.

Dani, S. (2014). Profitability Determinants of Indian Banks - Empirical Study. International Journal of Advanced Research in Management and Social sciences, 3 , 174-198.

Davydenko, A. (2010). Determinants of Bank Profitability in Ukraine. Undergraduate Economic Review, 7(1), 130.

Dawood, U. (2014, March). Factors impacting profitability of commercial banks in Pakistan for the period of (2009-2012). International Journal of Scientific and Research Publications, 4(3), 1-7.

Driver, R. (2008). Public Attitude to Inflation and Interest Rate.

Duraj, B., \& Moci, E. (2013). Factors Influencing the Bank Profitability - Empirical Evidence from Albania. Romanian Economic and Business Review , 10(1), 60-72.

Duraj, B., \& Moci, E. (2015). Factors Influancing the Banks Profitability- Epirical Evidence from Albaia. University of Tirana. Albania: AESS Publications.

Elefachew, M., \& Rao, H. P. (2016, October). The impact of industrial diversification on Ethiopian banks' profitability. International Journal of Commerce and Management Research, 2(10), 13-17.

Fentaw, F. L. (2012). Meta Analysis on The Determinants of Commercial Bank's Profitability: (A Conceptual Frame Work and Modeling). Europian Scientific Journal, 11, 323-351.

Fortun News. (2015). Retrieved December 30, 2016, from Addis Fortun Web site.

Francis, M. E. (2013, August 9). Determinants of Commercial Banks Profitability in Sub-Saharan Africa. International Journal of Economic and Finance, 5(9), 134-147. 
Gemechu, S. A. (2016, February). Determinants of Banks' Profitability Evidence from BankingIndustry in Ethiopia. International Journal of Economics, Commerce and Management, IV(2), 442-463.

Gujarati. (2004). Basic Econometrics (Fourth ed.).

Haron, S. (2004, March). Determinants of Islamic Bank Profitability. Global Journal of Finance and Economics, 1(1), 1-22.

Hassan, K., \& Bashir, A.-H. (2002). Determinants of Islamic Banking Profitability. Jeddah,Saudi Arabia.

Hausman, J. (1978). Specification Test in Econometrics. Econometrica, 1251-1271.

Hoffmann, P. S. (2011, December). Determinants of the Profitability of the US Banking Industry. International Journal of Business and Social Science, 2(22), 225-269.

Islam, S., \& Nishiyama, S.-I. (2015). The determinants of bank profitability: dynamic panel evidence from South Asian countries. Sendai.

Kokobe, A. S., \& Birhanu, N. D. (2015). Detreminants of Financial Performance of Commercial Banks in Ethiopia . Journal of Business Management and Economics, 3(11), 33-40.

Kosmidou, K., Tanna, S., \& Pasiouras, F. (2012). Determinants of profitability of domestic UK commercial banks: panel evidence from the period 1995-2002.

Kothari, R. C. (1995). Research Methodology (Second ed.). New Age International Publisher.

Krugman, P. K., \& Obstfeld, M. (2004). International Economics Theory and Policy (7th ed.). Pearson AddisonWesley.

Madura, J. (2010). Financial Markets and Institutions. Florida: Joi Sabatineo.

National Bank of Ethiopia. (2016). About Us. Retrieved 12 17, 2016, from National Bank Of Ethiopia Web Site: http://www.nbe.gov.et

Nisar, S., Sushing, W., Ahmed, J., \& Ke, P. (2015, April). Determinants of Banks Profitability in Pakistan: A latest Panel Data Evidence. International Journal of Econoics, Commerce and Management, III(4), 1-16.

Obamuyi, T. M. (2013). Determinants of Banks' Profitability in a Developing Economy: Evidence from Nigeria. Organizations and Markets in Emerging Econmies, 4(2(8)), 97-111.

Ponce, A. T. (2009). What Determines the Profitability of Banks? Evidence from Spain. Pablo de Olavide University, Departoment of Business Administration.

Rao, R. M., \& Tekeste, L. B. (2012, September). Determinants of Profitability of Commercial Banks in a Developing Country Evidence from Ethiopia. International Journal of Accounting and Financial Management research , 2(3), 1-20.

Roman, A., \& Danuletiu, A. E. (2013). An Empirical Analysis of the Determinants of Bank Profitability in Romania. Annales Universitatis Appulensis Series Oeconomica, 580-593.

Saeed, M. S. (2014). Bank-Related, Industry-Related and Macroeconomic Factors Affecting Banks Profitability: A Case of the United Kigdom Research. Journal of Finance and Accounting, 5(2).

Said, R. M., \& Tumin, M. H. (2011, March). Performance and Financial Ratios of Commercial Banks in Malaysia and China. International Review of Business Research Paper, 7, 157-169.

Saini, P., \& Sindhu, J. (2014, February). Role of Commercial Banks in the Economic Development of INDIA. International Journal of Engineering and Management Research, 4, 27-31.

Samuel, A. (2015). Determinants of Commercial Bank Profitability: The case of Ethiopian Commercial Banks. Msc Thesis, Addis Ababa University, Addis Ababa, Ethiopia.

Saunder, M., Lewis, P., \& Thornhill, A. (2009). Research methods for business students (Fifth Edition ed.). Prentice Hall.

Schipper IV, J. E. (2013). The Determinants of Bank Profitability Through the Global Financial Crisis: Evidence from Slovakia and Poland. Haverford college, Department of Economics.

Shapiro, S. S., \& Wilk, M. B. (1965, December). An Analysis of Variance Test for Normality (Complet Sample). 52(4), 591-611.

Sharma, P., \& Gounder, A. (2012). Profitability determinants of deposit institutions in small, underdeveloped financial systems the case of Fiji. Griffith University, Brisbane, QLD, Australia.

Siregar, R. (2011). Macro-prudential Approaches of Banking Regulation: Perspectives of Selected Asian Centeral Bank. Asian Development Bank Institution.

Sufian, F. (2011). profitability of the Korean Banking Sector Panel Evidence on Bank Specific and Macroeconomic Determinants. Journal Economics and Management, 7(1), 43-72.

Tadesse, G. (2015). The Impact of Exchange Rate on the Profitability of Commercial banks in Ethiopia. MsC Thesis, Addis Ababa University, Accounting and Finance, Addis Ababa.

Todorovic, M., \& Velickovic, M. (2010). The Impact of Exchange Rate Depreciation on Business Conditions in Serbia. Economic and Organization, 7(3), 263-270.

Tsalkitzidis, K. (2011). Determinan Banks Profitability in Greece and Balkans' before and during Financial Crisis.

Usman, M., Tarig, W., \& Mir, H. Z. (2014). Determinants of Commercial Banks Profitability Empirical Evidemce from Pakistan. International Journal of Accounting and Financial reportinng, 4(2), 1-22. 
Wooldridge, J. M. (2002). Introductory Econometrics: A Modern Approach (2nd ed.).

Yalemselam, B. W. (Nov. 1 2019). Factors Affecting Profitability of Banks: Empirical Evidence from Ethiopian Private Commercial Banks. Journal of Investment and Management, 8, 8-15.

Zikmund, W. G., Babin, B. J., Carr, J. C., \& Griffn, M. (2009). Business Research Methods (Eighth ed.). 